Matematikai Közlemények

IV. kötet, 2017

doi:10.20312/dim.2017.04

\title{
A vízterhelés, a vízgyưjtő és vízválasztó vonalak meghatározása az eső beszivárgásának és szétfolyásának modellezésével
}

\author{
Kalmár János \\ MTA CSFK GGI \\ kalmar@ggki.hu \\ Benedek Judit \\ MTA CSFK GGI \\ benedek@ggki.hu
}

\begin{abstract}
ÖSSZEFOGLALÓ. Rácsbázisú véges-elem esőzési/szétfolyási modellt használtunk alpesi jellegủ domborzat mellett a talaj vízterhelésének és a vízgyüjtő-vízválasztó vonalak meghatározására. A geodinamikai mérések szerint esőzés alatt és után a dőlésmérők jelentős anomáliákat regisztráltak. A modellezés kimutatta, hogy a vízterhelés gravitációs hatása a dőlésmérő által mutatott eső utáni anomália töredékét képes csak megmagyarázni. Ezután egy tisztán szétfolyási modellel a terep vízgyüjtő és vízválasztó vonalait határoztuk meg, ami - a domborzati viszonyokat figyelembe véve - tesztterületünkön maradéktalanul helytálló eredményeket hozott.
\end{abstract}

\begin{abstract}
A grid-based finite element run-off / drainage model was used on alpine terrain to determine soil water loading and water catchment area and water separation lines. According to geodynamic measurements (tilt meters records) significant anomalies are recorded during and after rainfalls. Our modelling has support that the gravitational effect of water can only explain a fraction of the postrain anomaly shown by the tilt meter. Then, with a purely flush model, we determined the lines of the catchment areas and the water separator of the terrain, which, taking into account the terrain conditions, gave realistic results in our test area.
\end{abstract}

\section{Bevezetés}

A tesztterület változatos domborzata (1. ábra) miatt nyilvánvaló, hogy a talaj csapadékból származó vízterhelése egyenlőtlen lesz a völgyek vízgyüjtő, illetve a gerincek vízválasztó hatása miatt, de nem ismertük ennek lehetséges mértékét és hatását dőlésmérővel végzett mérésekre. A gerinceken csak némi beszivárgással számoltunk, de a völgyekben, gödrökben a leesett csapadék többszöröse is összegyülhet, és a tömegnövekedés a lokális gravitációs erőtérre is hatással van, melynek mértékét a dolgozatban előállított modellel becsülni tudjuk.

A szakirodalom [1] szerint a talajba beszivárgó víz (talajtípustól függően) elsősorban függőlegesen halad lefelé, amíg vízzáró réteghez (pl. agyag) nem ér. A beszivárgás révén a talaj víztartalma folyamatosan nő, amíg el nem éri a telítettséget, ekkor megszünik a beszivárgás, és a víz elkezd a felszínen felhalmozódni, vagy ha a dőlésviszonyok lehetővé teszik, akkor a felszínen folyik tovább. 


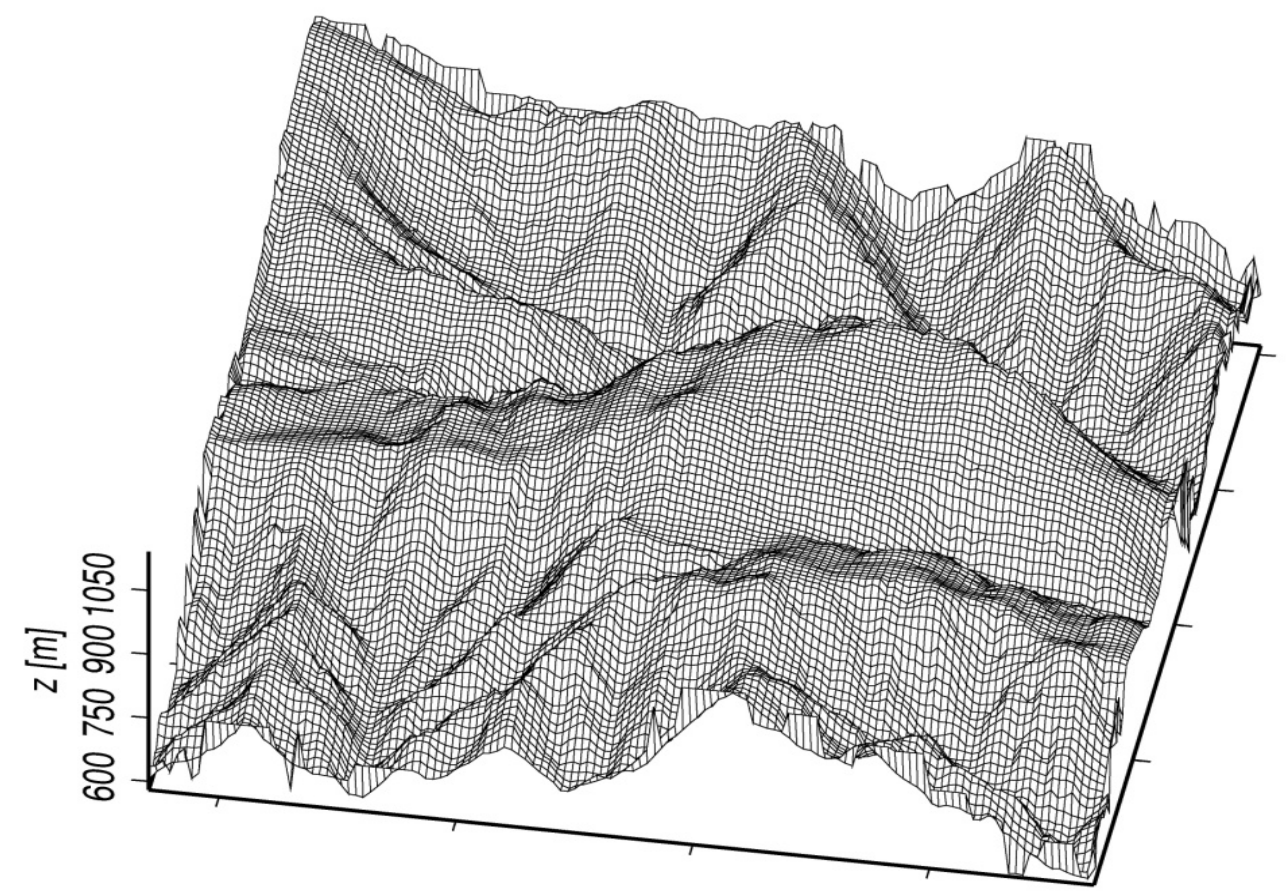

1. ábra. A tesztterület perspektivikus képe. Horizontális skálázás 1 km-ként

\section{Modell a tallaj vízterhelésének meghatározására}

A csapadéknak a talajfelszíni illetve felszín alatti vízháztartásra gyakorolt hatását rácsbázisú véges-elemes módszerrel modelleztük. A vizsgált terület rács-szerkezetü digitális terepmodelljét (DTM) a $h_{i, j}$ talajfelszín magasságokkal írjuk le [2], amit a későbbi képletek egyszerüsítése végett mm-ben mérünk.

Legyen adott ugyanezen a rácson a talajt borító vízréteg $h w_{i, j}$ magassága (ez kezdetben ott nem 0 , ahol permanens folyóvíz vagy állóvíz van), szintén mm-ben.

Legyen adott ugyanezen a rácson a talaj $v_{i, j}$ vízfelvevő potenciálja mm-ben (ahol a talajt állandó vízréteg borítja, ott nyilván 0 , mert már telítődött, ettől távolodva viszont elkezd emelkedni a csökkenő talajnedvesség miatt), mert ebben mérjük a csapadék vízhozamát is. Homogén, víz által nem borított talajon ezt konstansnak vettük, bár a valóságban a mélyebben fekvő területeken a magasabb talajvízszint miatt várhatóan alacsonyabb lesz a vízfelvevő potenciál, illetve mértéke a talajtípusnak is függvénye - erre vonatkozó rácsadatokkal sajnos nem rendelkeztünk.

Modellünkben feltettük, hogy egységnyi idő alatt a talajba beszivárgó $b_{i, j}$ vízmennyiség (mm-ben mérve) arányos a $v_{i, j}$ vízfelvevő potenciállal ([1], 34-35. oldal grafikonjából és képleteiből levezethető), de nem lehet nagyobb a felszíni $h v_{i, j}$ vízpotenciálnál:

$b_{i, j}=\min \left(h v_{i, j},\left\{\alpha \cdot v_{i, j}\right.\right.$, és $\left.\left.0<\alpha<1\right\}\right)$, ahol $\alpha$ a beszivárgási tényező.

A hosszan tartó esőzést osszuk fel egyforma időszakaszokra, és feltételezzük azt, hogy az aktuális időszakaszban $e$ mm eső esett. Ekkor

(1) $h v_{i, j}=h w_{i, j}+e, \quad$ ennyi mm lesz az új felszíni vízmagasság (vízpotenciál) az eső miatt; ez a kezdő állapot a következő időszakaszban.

$b_{i, j} \quad$ jelölje az aktuális beszivárgást. 


$$
\begin{array}{ll}
v_{i, j}=v_{i, j}-b_{i, j} & \text { így csökken a beszivárgási kapacitás. } \\
h v_{i, j}=h v_{i, j}-b_{i, j} & \text { a beszivárgás miatt csökken a felszíni vízpotenciál. } \\
h w_{i, j}=h v_{i, j} & \text { a szétfolyás elötti állapot duplikálása. }
\end{array}
$$

Ha az $(i, j)$ rácselem nem lokális minimumpont (pl. gödör), akkor lejtésirányban elfolyik róla a felszíni vízréteg egésze $\left(h v_{i, j}=0\right)$ vagy része, és a magasságkülönbségek arányában azt az oldalszomszéd rácspontok veszik fel. Ennek meghatározásához a következő összefüggéseket írtuk fel. Legyen

$d_{m, n}=\max \left(0, h_{i, j}+h v_{i, j}-h_{i+m, j+n}-h v_{i+m, j+n}\right)$, ahol $m=-1,0,1 ; \quad n=-1,0,1$ és $m \cdot n=0$, ahol $d_{m, n}$ jelöli szintkülönbséget az oldalszomszéd pontokhoz képest, figyelembe véve a vízborítottságot is.

$s=\sum d_{m, n}$, ahol $m=-1,0,1 ; n=-1,0,1$ és $m \cdot n=0$,

az összes szintkülönbség.

$d_{m, n}=d_{m, n} / s$, ahol $m=-1,0,1 ; n=-1,0,1$ és $m \cdot n=0$,

a fajlagos szintkülönbség.

$c \leq h v_{i, j}, \quad c \leq s \cdot d_{m, n} /\left(1+d_{m, n}\right)$, ahol $m=-1,0,1 ; n=-1,0,1$ és $m \cdot n=0$, a $c$ szétfolyás nem lehet több, mint a felszíni vízpotenciál, és szétfolyás után a rácselem nem kerülhet a szomszédok alá.

$h w_{i+m, j+n}=h w_{i+m, j+n}+c \cdot d_{m, n}$, ahol $m=-1,0,1 ; \quad n=-1,0,1$ és $m \cdot n=0$, az oldalszomszédok felszíni vízpotenciáljának növekedése.

$h w_{i, j}=h w_{i, j} \mathrm{j}-c, \quad$ a szétfolyással csökken a rácspont felszíni vízpotenciálja.

goto (1) lezárult egy esőzési ciklus, és továbbléphetünk a következő esőzési fázisba.

Ha vége van az esőnek, stabilizáció (azaz leáll a beszivárgás és a szétfolyás) után rácselemenként meghatározhatjuk a beszivárgás és a szétfolyás okozta tömegnövekedést, ami a $h w$ felszíni vízpotenciál növekedésével és $v$ vízfelvevő potenciál csökkenésével arányos (szorzóként figyelembe veendő a víz fajsúlya és a rácselem területe. Magasságát, és ezzel térfogatát az előbb számított felszín alatti és feletti vízpotenciál-változások összege adja).

Az eljárást egy horizontálisan $4 \mathrm{~km} \times 4 \mathrm{~km}$ kiterjedésű, $30 \mathrm{~m} \times 30 \mathrm{~m}$ felbontású alpesi DTM-en (1. ábra) 10 ciklusos esőzési (ciklusonként $e=10 \mathrm{~mm}$ csapadékkal) és 90 ciklusos csapadékmentes $(e=0 \mathrm{~mm})$ stabilizáló folyamattal teszteltük. Az $\alpha$ beszivárgási tényezőt 0.1-nek választottuk, a $v_{i, j}$ vízfelvevő potenciált pedig $100 \mathrm{~mm}$-nek tekintettük a teljes tartományon. Ha nincs szétfolyás, az összes csapadék beszivárgott volna a talajba, de a meredek domborzat miatt csak 80 \%-os volt az elszivárgás, a maradék víz olyan vízgyüjtő (lokális minimum) helyeken gyült össze, melyek a teljes területnek csak 2,3\%-át fedték le (2. ábra). A lehullott csapadék párolgását nem vettük figyelembe.

\section{Modell a vízgyűjtő és vízválasztó vonalak meghatározására}

A vizsgálatot kiterjesztettük a vízgyüjtő és vízválasztó vonalak meghatározására is. A fenti modellt annyiban módosítottuk, hogy egy méter $h w_{i, j}$ vízborításból indulva csapadékutánpótlás és beszivárgás nélkül meghatároztuk, mennyi víz folyik át/gyülik össze az egyes rácselemeken a domborzati lejtőviszonyok miatt. Az adatok elemzésekor kiderült, hogy 100 szétfolyási ciklus után a rácselemek vízpotenciál függvényének hisztogramja (3. ábra) a $k=3$ paraméterü $\mathrm{Khi}^{2}$ eloszlásra emlékeztet. Tapasztalataink szerint a módusz (legvalószínűbb érték, esetünkben $0.04 \mathrm{~m}$ ) alatti vízborítású rácselemek vonalszerü (fehér) foltként jelölik ki a vízválasztó vonalakat, a vízgyüjtő vonalakat pedig a medián $(0.15 \mathrm{~m})$ tízszeresénél nagyobb vízpotenciálú (sárga-zöld-kék árnyalatú) rácselemek alkotják (4. ábra). 


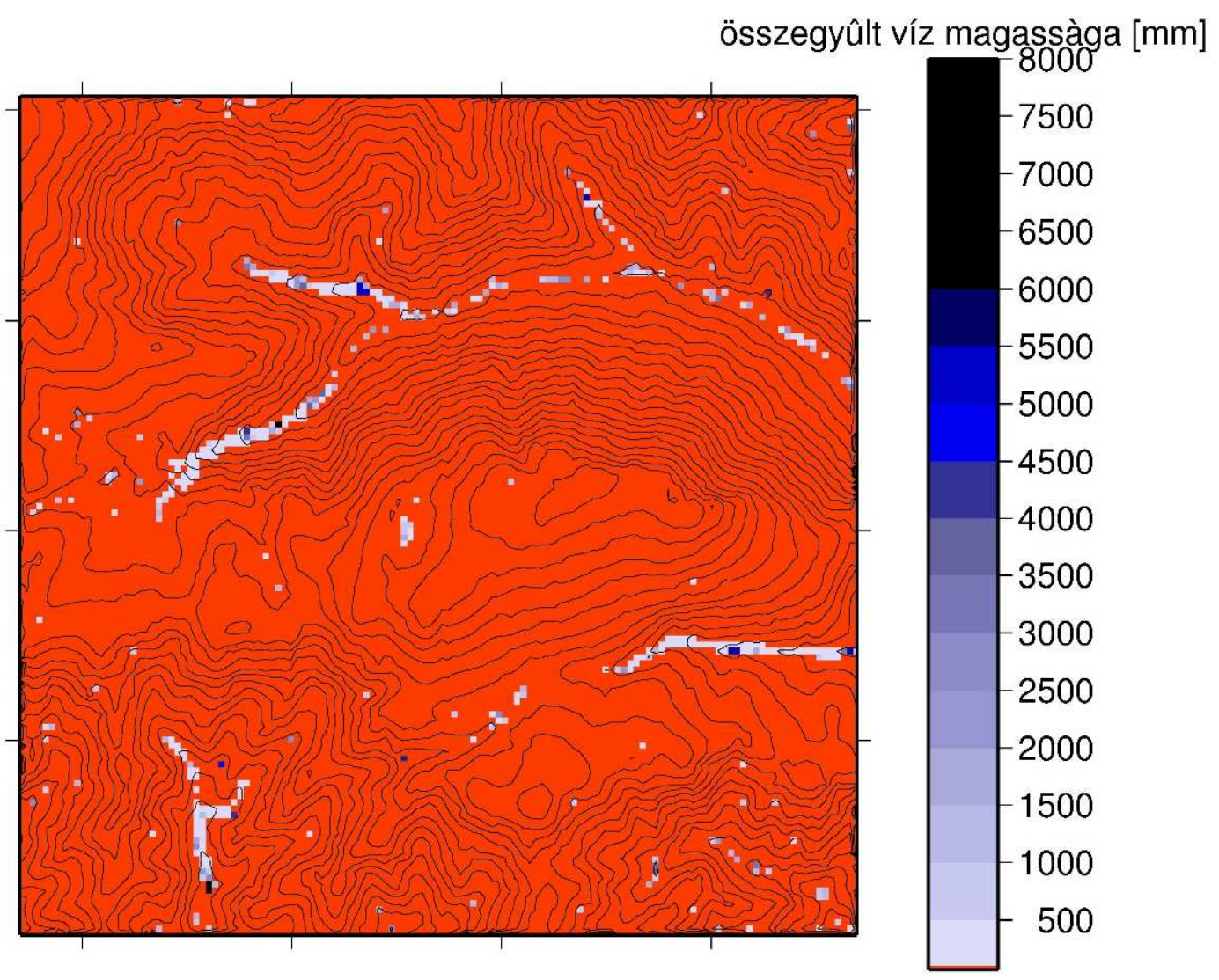

2. ábra. A tesztterület felszíni vízmagassága eső után. A területet km-enként skáláztuk. A domborzat-ábrázolás szintvonalköze 25 m

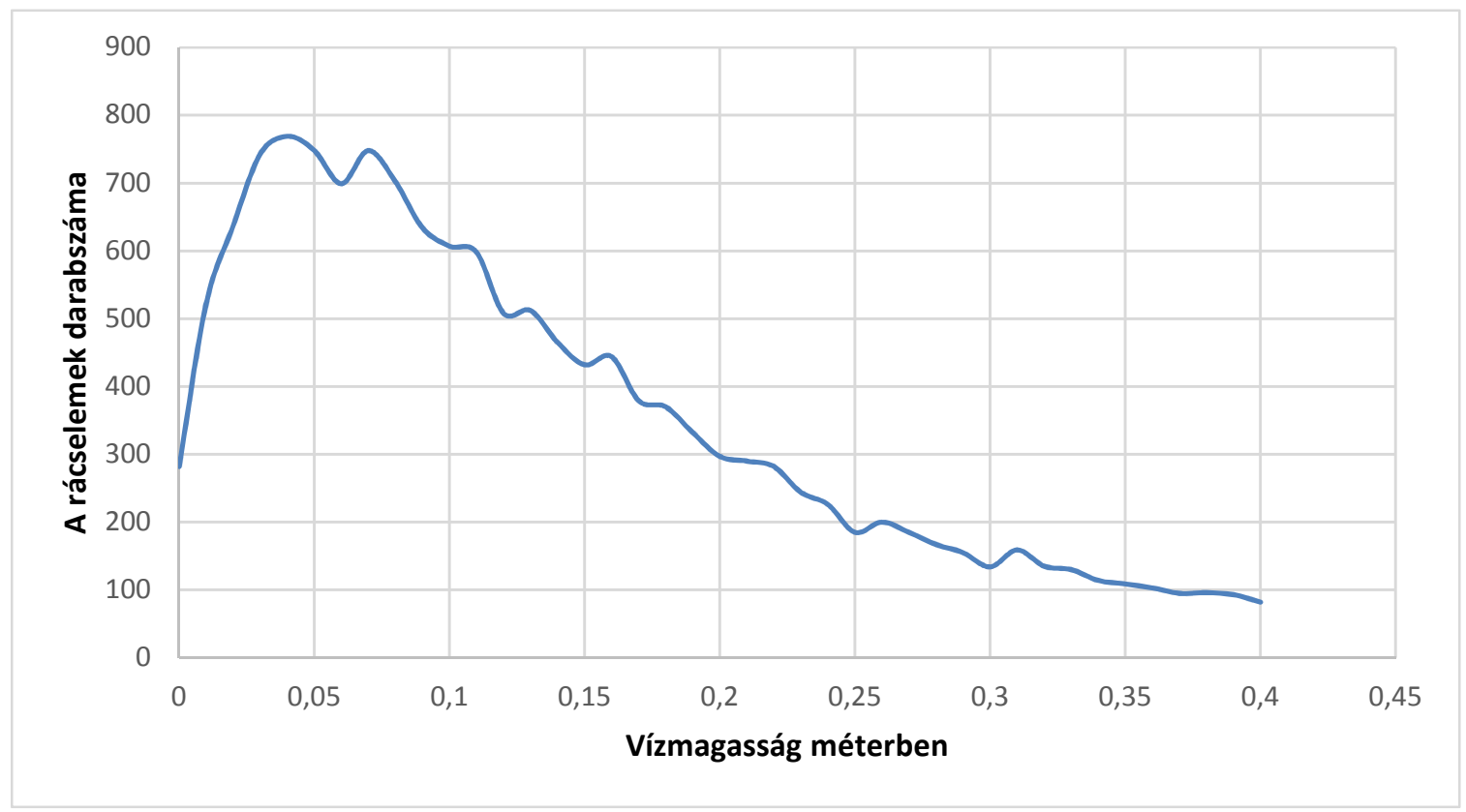

3. ábra. A vízpotenciál gyakorisági hisztogramja szétfolyás után 


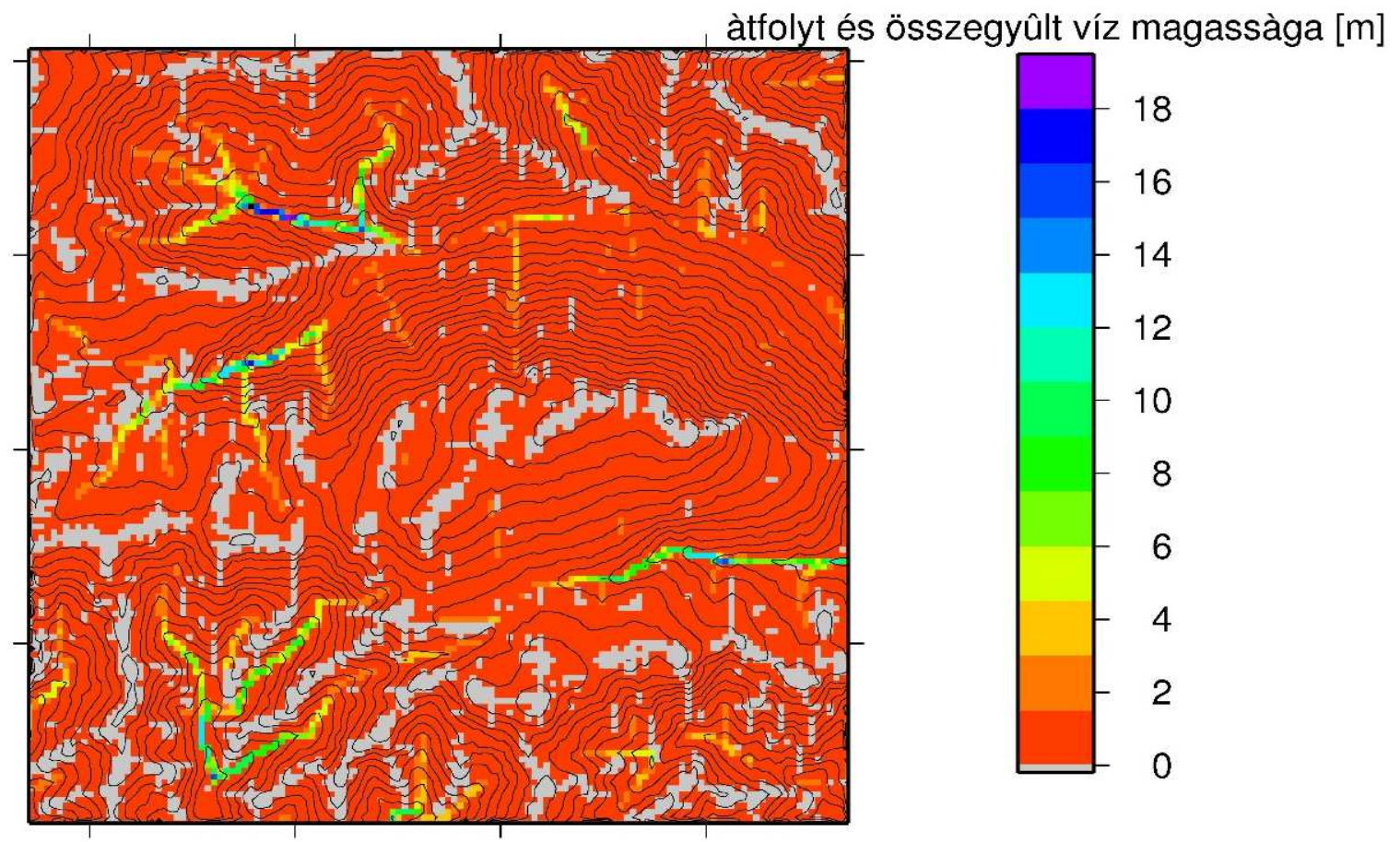

4. ábra. A tesztterület vízgyűjtő és vízválasztó vonalai. A területet km-enként skáláztuk. A domborzat-ábrázolás szintvonalköze 25 m

\section{4. Összefoglaló}

Rácsbázisú véges-elem modellezéssel szimuláltuk a csapadék hatását a felszín vízborítottságára, illetve a talaj víztelítettségére. Papp Gábor kollégánk megállapította, hogy a szétfolyási és beszivárgási modell alapján számított vízterhelés gravitációs hatása a dőlésmérő által mutatott eső utáni anomália töredékét képes csak megmagyarázni. Egy tisztán szétfolyási modellel a terep vízgyüjtő és vízválasztó vonalait határoztuk meg, ami tesztterületünkön figyelembe véve a domborzati viszonyokat - maradéktalanul helytálló eredményeket hozott.

\section{Köszönetnyilvánítás.}

Köszönjük Dr. Papp Gábornak (MTA CSFK Geodéziai és Geofizikai Intézet, Sopron) és Prof. Dr. Bruno Meurersnek (TU Wien Institut für Meteorologie und Geophysik), hogy munkánkat tanácsokkal és adatokkal segítették.

\section{Irodalomjegyzék}

[1] Varga Cs., A talaj víz-, hő- és levegőgazdálkodása, (http://zeus.nyf.hu/ tkgt/okse/tatata08/tata0811.pdf) 2015.

[2] Kalmár J, A digitális terepmodell kutatások új eredményei, kandidátusi értekezés, 1994. 